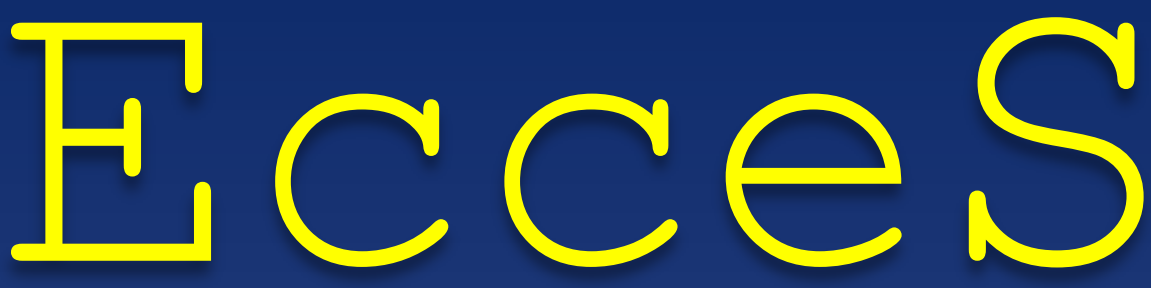

Economics, Social, and Development Studies

POSISI PENDUDUK KOTA MAKASSAR DALAM MENUNJANG

PEMBANGUNAN EKONOMI

Abdul Rahman dan Nur Rahmi Hamzah

EFISIENSI BELANJA PEMERINTAH DI SEKTOR PENDIDIKAN DAN KESEHATAN

DI PROVINSI SULAWESI SELATAN

Rapiuddin dan Bahrul Ulum Rusydi

STRUKTUR EKONOMI DAN POLA PEMBANGUNAN DAERAH

DI KAWASAN MAMMINASATA

Husni Mubarak dan Hasbiullah

PENGARUH PENGELUARAN PEMERINTAH DAN UPAH MINIMUM REGIONAL (UMR) TERHADAP TINGKAT PARTISIPASI ANGKATAN KERJA DI KOTA MAKASSAR

Ikhwan dan Siradjuddin

PENGARUH TENAGA KERJA DAN PENGELUARAN PEMERINTAH TERHADAP PERTUMBUHAN EKONOMI KOTA MAKASSAR

Irmayanti dan Aulia Rahman Bato

FAKTOR-FAKTOR YANG MEMENGARUHI PRODUKSI JAGUNG DI DESA TANAH TOWA KECAMATAN KAJANG KABUPATEN BULUKUMBA

Kamaluddin dan Andi Faisal Anwar

ANALISIS PENENTUAN SEKTOR UNGGULAN DAN PERUBAHAN STRUKTUR EKONOMI KABUPATEN JENEPONTO TAHUN 2011-2015

Syaripuddin dan Abdul Wahab 


\section{Ecces}

Economics, Social, and Development Studies

VOLUME 4 NOMOR 1 JUNI 2017

POSISI PENDUDUK KOTA MAKASSAR DALAM MENUNJANG

PEMBANGUNAN EKONOMI

Abdul Rahman dan Nur Rahmi Hamzah

EFISIENSI BELANJA PEMERINTAH DI SEKTOR PENDIDIKAN DAN KESEHATAN DI PROVINSI SULAWESI SELATAN

Rapiuddin dan Bahrul Ulum Rusydi

STRUKTUR EKONOMI DAN POLA PEMBANGUNAN DAERAH DI KAWASAN MAMMINASATA

Husni Mubarak dan Hasbiullah

PENGARUH PENGELUARAN PEMERINTAH DAN

UPAH MINIMUM REGIONAL (UMR) TERHADAP TINGKAT PARTISIPASI

ANGKATAN KERJA DI KOTA MAKASSAR

Ikhwan dan Siradjuddin

PENGARUH TENAGA KERJA DAN PENGELUARAN PEMERINTAH TERHADAP PERTUMBUHAN EKONOMI KOTA MAKASSAR

Irmayanti dan Aulia Rahman Bato

FAKTOR-FAKTOR YANG MEMENGARUHI PRODUKSI JAGUNG DI DESA TANAH TOWA KECAMATAN KAJANG KABUPATEN BULUKUMBA

Kamaluddin dan Andi Faisal Anwar

ANALISIS PENENTUAN SEKTOR UNGGULAN DAN PERUBAHAN STRUKTUR EKONOMI KABUPATEN JENEPONTO TAHUN 2011-2015

Syaripuddin dan Abdul Wahab 


\title{
PENGARUH PENGELUARAN PEMERINTAH DAN UPAH MINIMUM REGIONAL (UMR) TERHADAP TINGKAT PARTISIPASI ANGKATAN KERJ A DI KOTA MAKASSAR
}

\author{
Ikhwan ${ }^{1}$ \\ Siradjuddin ${ }^{2}$
}

\begin{abstract}
ABSTRAK
Penelitian ini bertujuan untuk mengetahui bagaimana pengaruh pengeluaran pemerintah dan upah minimum regional terhadap tingkat partisipasi angkatan kerja di Kota Makassar. Data yang digunakan adalah periode 20052014. Hasil analisis menunjukkan bahwa variabel pengeluaran pemerintah berpengaruh positif dan signifikan terhadap tingkat partisipasi angkatan kerja di Kota Makassar, sedangkan upah minimum regional berpengaruh negatif dan signifikan terhadap TPAK.
\end{abstract}

Kata kunci: Pengeluaran pemerintah, UMR, TPAK, Makassar

\section{PENDAHULUAN}

Telah menjadi rahasia umum bahwa permasalahan yang di hadapi oleh kebanyakan negara sedang berkembang adalah masalah penduduk dan lapangan kerja. Dimana terdapat jumlah penduduk yang besar dengan lapangan pekerjaan yang terbatas sehingga tidak mampu menampung secara keseluruhan angkatan kerja yang tersedia. Hal seperti ini tentunya akan meningkatkan pengangguran yang akan menjadi beban negara pada akhirnya.

Tenaga kerja merupakan faktor terpenting dalam kegiatan perekonomian Sebagai sarana dalam suatu kegiatan ekonomi seperti produksi, tenaga kerja dianggap lebih penting daripada sarana produksi lainnya seperti bahan mentah dan sebagainya. Tidak semua penduduk merupakan tenaga kerja, hanya penduduk yang telah mencapai umur minimum tertentu baru bisa dianggap sebagai tenaga kerja potensial atau angkatan kerja. Selain itu, tidak semua tenaga kerja terlibat dalam kegiatan ekonomi.

Perekonomian yang berkembang pesat tidak hanya merupakan jaminan yang baik terhadap sulitnya mencari kerja dikalangan tenaga kerja. Akan tetapi, juga sangat penting untuk dapat menyerap tenaga-tenaga kerja baru yang setiap

1 Universitas Islam Negeri Alauddin Makassar

2 Universitas Islam Negeri Alauddin Makassar, bahrul.rusydi@uin-alauddin.ac.id 
tahunnya memasuki pasaran kerja. Kurangnya kesempatan kerja yang dapat disediakan oleh pemerintah dengan jumlah angkatan kerja yang semakin lama semakin bertambah, menyebabkan tidak terserapnya tenaga kerja secara keseluruhan.

Tidak hanya terbatas pada cakupan negara saja, permasalah tentang penduduk dan tenaga kerja juga dialami oleh setiap daerah. Kota Makassar yang merupakan salah satu wilayah dengan pertumbuhan ekonomi yang pesat juga tidak terlepas dari permasalahan tenaga kerja, seperti penyerapan tenaga kerja, sampai pada seberapa besar tingkat partisipasi angkatan kerjanya dalam kegiatan ekonomi. Maka dari itu penanganan yang tepat terhadap penduduk dan tenaga kerja ini haruslah tepat.

Pemerintah selaku fasilitator serta pengawas tentunya akan menyediakan lapangan kerja serta akan mengawasi produk/kebijakan yang dikeluarkannya. Pengeluaran pemerintah (goverment expenditure) adalah bagian dari kebijakan fiskal (Sadono Sukirno,2000:346) yaitu suatu tindakan pemerintah untuk mengatur jalannya perekonomian dengan cara menentukan besarnya penerimaan dan pengeluaran pemerintah setiap tahunnya. Yang salah satu tujuannya yaitu untuk menstabilkan kesempatan kerja.

Selanjutnya, pemerintah tidak hanya memberikan wadah berupa lapangan pekerjaan tetapi juga harus mengawal setiap kegiatan ekonomi tersebut. Seperti dengan memperhatikan tingkat upah yang diperoleh tenaga kerja, yang merupakan salah satu faktor yang mempengaruhi Tingkat Partisipasi Angkatan Kerja (TPAK). Upah merupakan faktor yang dianggap penting karna upah merupakan penyebab sebagian dari tenaga kerja untuk masuk atau tidak ke pasar tenaga kerja. Jika tingkat upah tinggi masyarakat akan semakin banyak masuk ke dalam pasar tenaga kerja yang akan meningkatkan pula tingkat partisipasi angkatan kerja, dan begitu pula sebaliknya.

\section{TINJ AUAN PUSTAKA}

\section{Tingkat Partisipasi Angkatan Kerja (TPAK)}

Menurut Simanjuntak (1985:7) tingkat partisipasi angkatan kerja adalah perbandingan antara jumlah angkatan kerja dan penduduk usia kerja dalam kelompok yang sama. TPAK digunakan untuk mengindikasikan besaran 
persentase penduduk usia kerja yang aktif secara ekonomi di suatu negara/wilayah. Semakin tinggi TPAK menunjukkan bahwa semakin tinggi pula pasokan tenaga kerja (labour supply) yang tersedia untuk memproduksi barang dan jasa dalam suatu perekonomian.

Menurut Sony Sumarsono (2003:86) salah satu faktor yang mempengaruhi besarnya TPAK adalah kegiatan ekonomi. Di mana belanja modal yang dilakukan oleh pemerintah merupakan salah satu bentuk kegiatan ekonomi, dengan tujuan pertumbuhan dan pembangunan ekonomi. Program pembangunan disatu pihak menuntut keterlibatan banyak orang, dan dipihak lain program pembangunan menumbuhkan harapan-harapan baru. Harapan untuk dapat ikut menikmati hasil pembangunan tersebut yang dinyatakan dalam peningkatan tingkat partisipasi angkatan kerja. Jadi, semakin bertambah kegiatan kegiatan ekonomi semakin besar pula TPAK suatu daerah/wilayah tersebut.

\section{Pengeluaran Pemerintah}

Menurut Mangkoesoebroto $(2008,169)$ pengeluaran pemerintah mencerminkan kebijakan pemerintah, apabila pemerintah telah menetapkan suatu kebijakan untuk membeli barang dan jasa. Pengeluaran pemerintah mencerminkan biaya yang harus dikeluarkan oleh pemerintah untuk melaksanakan kebijakan tersebut.

\section{Tingkat Upah}

Pengertian upah menurut Undang-Undang Tenaga kerja No. 13 tahun 2000, Bab I, pasa I, ayat 30 : "upah adalah hak pekerja/buruh yang diterima dan dinyatakan dalam bentuk uang sebagai imbalan dari pengusaha/pemberi kerja kepada pekerja/buruh yang ditetapkan dan dibayarkan menurut suatu perjanjian kerja, kesepakatan atau peraturan perundang-undangan termasuk tunjangan bagi pekerja/buruh dan keluarganya atas suatu pekerjaan dan/atau jasa yang telah atau akan dilakukan.

Semakin tinggi tingkat upah yang ditawarkan dalam pasar tenaga kerja maka semakin banyak orang yang tergolong dalam usia kerja lebih cenderung untuk masuk ke dalam golongan ankatan kerja dibandingkan untuk masuk ke dalam golongan bukan angkatan kerja. Dan hal ini berpengaruh pada meningkatnya tingkat partisipasi angkatan kerja (TPAK). 


\section{METODE PENELITIAN}

Dalam penelitian ini, digunakan metode komparatif dan kuantitatif, yaitu membandingkan suatu permasalahan dan menganalisis data dan hal-hal yang berhubungan dengan angka-angka atau rumus-rumus perhitungan yang digunakan untuk menganalisis masalah yang sedang diteliti. Penelitian ini menggunakan analisis linear berganda dengan data runtut waktu (time series). Untuk menguji bisa atau tidak regresi tersebut digunakan dan untuk menguji hipotesis yang dilakukan, maka diperlukan pengujian statistik, sebagai berikut:

$$
\begin{aligned}
& Y=f\left(X_{1}, X_{2}\right) \\
& Y=\beta 0+\beta_{1} X_{1}+\beta_{2} X_{2}+e \mu
\end{aligned}
$$

Keterangan:

$$
\begin{aligned}
& Y_{1}=\text { Partisipasi Angkatan Kerja } \\
& X_{1}=\text { Pengeluaran Pemerintah } \\
& X_{2}=\text { UMR } \\
& \beta 0=\text { Bilangan Konstanta } \\
& \beta_{1}=\text { Koefisien Pengeluaran Pemerintah } \\
& \beta_{3}=\text { Koefisien UMR } \\
& \mu=\text { Error Term }
\end{aligned}
$$

\section{HASIL DAN PEMBAHASAN}

Berdasarkan hasil analisis melalui program SPSS 21 dengan metode regresi linear berganda, diperoleh hasil penelitian sebagai berikut:

Tabel Hasil Estimasi

\begin{tabular}{llll}
\hline Regressions & $\begin{array}{l}\text { Estimated } \\
\text { Coefficients }\end{array}$ & T Value & Sig \\
\hline TPAK & -9.747 & -4.050 & .005 \\
Pengeluaran & .599 & 5.161 & .001 \\
Pemerintah & -.177 & 2.373 & .049 \\
UMR & $=.873$ & & \\
\hline R-Squared & $=.837$ & & \\
Adjusted R-Squared & & \\
Durbin-Watson Statistic & $=1.629$ & \\
F-Statistic & $=24.060$ &
\end{tabular}


Hasil penelitian pada tabel tersebut menjelaskan bahwa secara statistik pengeluaran pemerintah berpengaruh signifikan (nilai sig $.001<$ taraf signifikansi $5 \%$ ) dan berpengaruh positif (nilai koefisien estimasi bernilai positif 0.599) terhadap TPAK. Sementara upah minimum regional (UMR) berpengaruh signifikan (nilai sig $.049<$ taraf signifikansi 5\%) dan berpengaruh negatif (nilai koefisien estimasi bernilai negatif -0.177 ) terhadap TPAK.

Nilai R-Squared menunjukkan bahwa variabel bebas yaitu pengeluaran pemerintah dan upah minimum regional memberikan kontribusi sebesar $87.3 \%$ terhadap perubahan dari variabel terikat yaitu tingkat pertisipasi angkatan kerja. Sedangkan sisanya sebesar $12.7 \%$ dipengaruhi oleh variabel lain diluar penelitian ini.

Pengeluaran pemerintah memiliki pengaruh signifikan dan berhubungan positif $(0,001>0,05)$ terhadap tingkat partisipasi angkatan kerja. Selanjutnya koefisien regresinya yaitu sebesar 0,599 menunjukkan bahwa setiap penambahan pengeluaran pemerintah $1 \%$ maka akan meningkatkan tingkat partisipasi angkatan kerja sebesar 0,6\%. Dengan melihat hasil analisis menunjukkan bahwa hubungan antara pengeluaran pemerintah terhadap tingkat partisipasi angkatan kerja memiliki hubungan yang positif dan berpengaruh signifikan. Hal ini disebabkan pengeluaran pemerintah di Kota Makassar cenderung berorientasi pada belanja modal. Sehingga tingginya pengeluaran pemerintah memberikan dampak yang besar terhadap pembangunan ekonomi di Kota Makassar. Hal ini berdampak pada meningkatnya angka tingkat partisipasi angkatan kerja.

Upah minimum regional memiliki pengaruh signifikan dan berhubungan negatif $(0,049>0,05)$ terhadap tingkat partisipasi angkatan kerja. Selanjutnya koefisien regresinya yaitu sebesar $-0,117$ akan menurunkan tingkat partisipasi angkatan kerja sebesar $0,12 \%$. Dengan melihat hasil analisis menunjukkan bahwa hubungan antara upah minimum regional terhadap tingkat partisipasi angkatan kerja memiliki hubungan yang negatif dan berpengaruh signifikan. Hal ini disebabkan oleh beberpa indikator diantaranya berkurangnya jumlah ankatan kerja pada saat terjadinya peningkatan upah, sepertinya yang terjadi pada tahun 2007 ke tahun 2008 dimana terjadi peningkatan upah sementara tingkat partisipasi angkatan kerjanya menurun. Atau dari tahun 2011 ke tahun 2012 dengan upah Rp 1.100.000,00 menjadi Rp. 1.200.000,00 ternyata menurunkan TPAK dari $62 \%$ menjadi $57,94 \%$. Pemberian upah yang tinggi diharapkan 
perusahaan dapat lebih meningkatkan produktifitas pekerjanya, sehingga tidak diperlukan lg penambahan karyawan. Dengan kata lain tidak adanya peningkatan jumlah angkatan kerja pada waktu atau periode tersebut.

\section{KESIMPULAN}

Berdasarkan hasil analisis data yang dilakukan dan pembahasan yang telah dikemukakan, maka diperoleh kesimpulan sebagai berikut:

1. Pengeluaran Pemerintah berpengaruh positif dan signifikan terhadap Tingkat Partisipasi Angkatan Kerja di Kota Makassar.

2. Upah Minimum Regional berpengaruh negatif dan signifikan terhadap Tingkat Partisipasi Angkatan Kerja di Kota Makassar.

\section{DAFTAR PUSTAKA}

Anis, Ananta. 1990. E konomi Sumber Daya Manusia. Jakarta:Lembaga Demografi Universitas Indonesia Fakultas Ekonomi.

Arsyad, Lincolin. 2009. Pengatur Perencanaan Pembangunan Ekonomi Daerah E disi Kedua.BPFE-YOGYAKARTA.

Bakri, Zaenab dan Manning, Chris. 1984. Angkatan Kerja Di Indonesia. Partisipasi, Kesempatan dan Pengangguran.Jakarta : CV Rajawali.

Dumairy. 1996. Perekonomian Indonesia. Jakarta:Erlangga.

Indriantoro. 1999. Metodologi untuk Aplikasi dan Bisnis.Yogyakarta: BPFEYOGYAKARTA.

Jhingan, M.L. 2008. Ekonomi Pembangunan dan Perencanaan. Jakarta:PT. RajaGrafindo.

Mangkoesoebroto, Guritno. 2013. Ekonomi Publik Edisi Ketiga.Yogyakarta : BPFE-YOGYAKARTA.

Mankiw, N Gregory.Makroekonomi Edisi Keenam.Jakarta : Erlangga.

Mubyarto. 1997. Ekonomi Rakyat Program IDT dan Demokrasi Ekonomi Indonesia. Yogyakarta:Aditya Media Publication.

Rahayu, Ani Sri. 2010. Pengantar Kebijakan Fiskal. Jakarta : PT Bumi Aksara.

Samuelson dan Nordhaus. 1996. Makroekonomi (terjemahan),E disi Keempat. Jakarta:Erlangga.

Simanjuntak, Payman. 2001.P engantar Ekonomi Sumber Daya Manusia. Jakarta : Lembaga Penerbit FE-UI.

Soeparmoko. 1994. Pengantar Ekonometrika Makro.Yogyakarta:BPFE.

Sukirno, Sadono. 2011. Makroekonomi Teori Pengantar. Jakarta : PT Raja Grafindo, Edisi Ketiga. 
Sumarsono, Sony. 2003. Ekonomi Manajemen Sumber Daya Manusia dan Ketenagakerjaan. Yogyakarta: Graha IImu.

Suryadi, Asep. 2003. Minimum Wage Policy and Its Impact on Employment in the Urban Formal Sector. BIES.

Todaro, Michael P. Dan Smith, Stephen C. 2003. Pembangunan Ekonomi di Dunia Ketiga, edisi Kedelapan. Jakarta: Erlangga.

Todaro. Michael p. (2000). Pembangunan ekonomi di dunia ketiga, edisi ketujuh terjemahan haris munandar. Jakarta: Erlangga. 


\section{E C C E S}

Economics, Social, and evelopment Studies

Jurusan IImu Ekonomi

Fakultas Ekonomi dan Bisnis Islam UIN Alauddin

Kampus II Jl. SIt Alauddin No.36 Samata Sungguminasa-Gowa Telp (424835)

Email: ecces@uin-alauddin.ac.id

Aturan penulisan Jurnal IImu Ekonomi Fakultas Ekonomi dan Bisnis Islam UIN Alauddin Makassar adalah sebagai berikut:

1. Artikel harus berupa tulisan asli, merupakan hasil penelitian maupun kajian dalam bidang ekonomi terapan dan belum pernah dipublikasikan di media manapun serta bebas dari unsur-unsur plagiarisme.

2. Artikel ditulis dalam Bahasa Indonesia dengan memenuhi kaidah EYD Bahasa Indonesia.

3. Sistematika penulisan:

a. Bagian awal: judul, nama penulis (dituliskan lengkap tanpa gelar), abstrak yang tidak lebih dari 300 kata dan diketik dengan satu spasi yang berisi latar belakang, tujuan, metodologi, dan hasil penelitian.

b. Bagian utama: pendahuluan, tinjauan teoritis dan pustaka, metode penelitian, hasil dan pembahasan, serta kesimpulan.

c. Bagian akhir: daftar pustaka, dan lampiran.

4. Judul artikel ditulis dengan menggunakan huruf kapital.

5. Teknik penulisan:

a. Alinea baru dimulai pada ketikan kelima pada batas tepi kiri. Antar alinea tidak diberi tambahan spasi.

b. Penggunaan kata asing ditulis dengan menggunakan huruf miring (italic).

c. Batas pengetikan: tepi kiri tiga $\mathrm{cm}$, tepi kanan dua $\mathrm{cm}$, tepi atas tiga $\mathrm{cm}$, dan tepi bawah dua $\mathrm{cm}$.

d. Tabel, gambar, dan ilustrasi lainnya diberikan judul, nomor, dan sumber yang jelas.

e. Sumber pustaka ditulis nama-tahun (nama belakang penulis, tahun penerbitan). Nama penulis harus tepat sama dengan yang tercantum dalam daftar pustaka.

6. Naskah diketik dengan MS Word, spasi satu, ukuran font 11, huruf Arial, dengan panjang minimum-maksimum 15-20 halaman (A4).

7. Tulisan harus dikirim paling lambat 1 bulan sebelum penerbitan jurnal ke email jurnal Ecces atau diserahkan langsung ke tim pengelola dalam bentuk CD.

8. Jurnal Ecces terbit 2 kali dalam setahun, yaitu Juni dan Desember.

9. Email jurnal Ecces: jurnalecces@gmail.com 


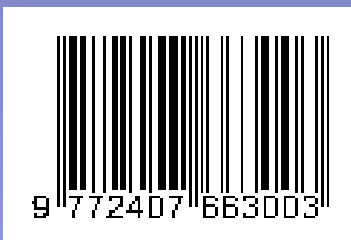

